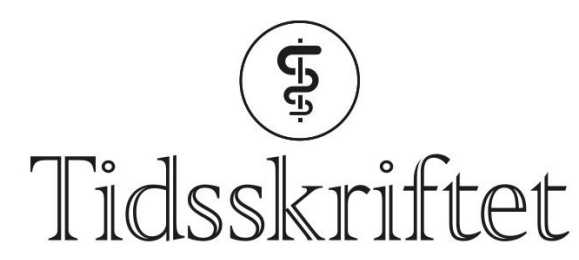

DEN NORSKE LEGEFORENING

\title{
Indre tarmbrokk
}

MEDISINEN I BILDER

MAGNUS BERLE

E-post: magnus.berle@gmail.com

Gastro- og akuttkirurgisk avdeling

Haukeland universitetssykehus

og

Universitetet i Bergen

Magnus Berle (f. 1983) er ph.d. og lege i spesialisering.

Forfatter har fylt ut ICMJE-skjemaet og oppgir ingen interessekonflikter.

\section{KRISTINE HERMANSEN DAHLSLETT}

Radiologisk avdeling

Haukeland universitetssykehus

og

Sørlandet sykehus, Arendal

Kristine Hermansen Dahlslett (f. 1982) er konstituert overlege og lege i spesialisering.

Forfatter har fylt ut ICMJE-skjemaet og oppgir ingen interessekonflikter.

\section{GIEDRE KAVALIAUSKIENE}

Radiologisk avdeling

Haukeland universitetssykehus

Giedre Kavaliauskiene (f. 1980) er overlege.

Forfatter har fylt ut ICMJE-skjemaet og oppgir ingen interessekonflikter.

\section{DAG HOEM}

Gastro- og akuttkirurgisk avdeling Haukeland universitetssykehus

Dag Hoem er ph.d. og seksjonsoverlege.

Forfatter har fylt ut ICMJE-skjemaet og oppgir ingen interessekonflikter. 


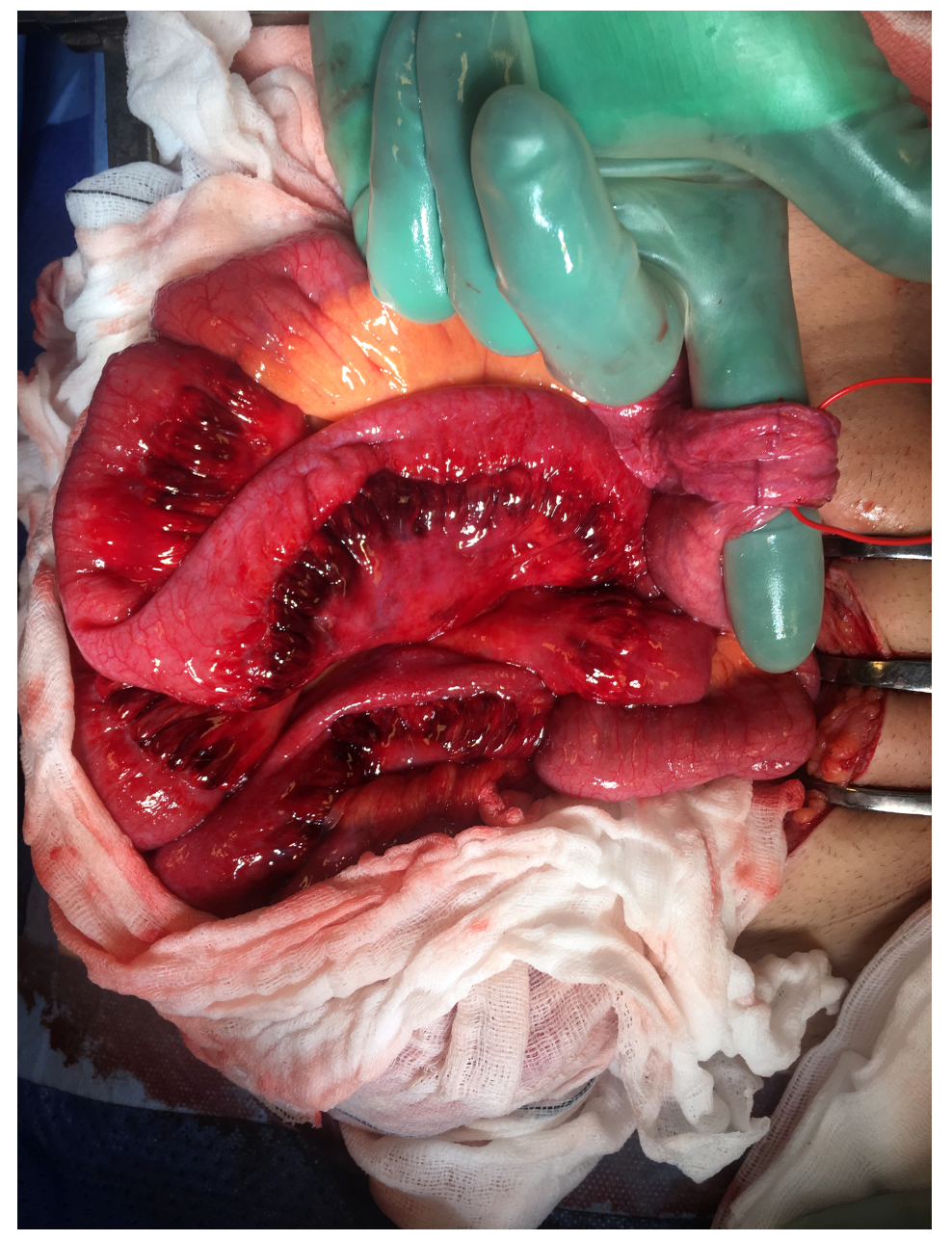

En tidligere frisk mann i 2o-årene ble innlagt i kirurgisk avdeling med smerter lokalisert sentralt i abdomen. Orienterende blodprøver og vitale parametere var upåfallende. Smertene avtok, og han ble utskrevet samme kveld med avtale om åpen retur. Etter utskrivning fra sykehuset var smertene moderate de første to døgnene. Tredje dag våknet han av sterke magesmerter. Ved undersøkelse på sykehuset samme dag var han kvalm. Buken var lett utspilt, og han var palpasjonsøm i høyre fossa iliaca. Orienterende blodprøver var fortsatt upåfallende.

CT-undersøkelse av abdomen viste hernierte tynntarmslynger gjennom en brokkport i mesenteriet, oppfattet som intern herniering.

Han ble operert med laparoskopisk tilgang som ble konvertert til åpen tilgang, da tarmen ikke lot seg reponere laparoskopisk. Tynntarmen var herniert inn i en lomme i peritoneum ca. $15 \mathrm{~cm}$ distalt for Treitz' ligament. Vel én meter tynntarm lå inn i en peritoneal brokksekk i et intramesenterisk brokk. Bildet viser brokksekken sammenfalt rundt fingeren og tynntarmen med ødem i mesenteriet. På bildet ses også lett misfarging av selve tarmen, forenlig med en delvis avklemming av sirkulasjonen. Brokkporten og sekken utgående fra peritoneum ble resesert. Pasienten ble utskrevet fjerde postoperative dag i god allmenntilstand.

Intern herniering er en klinisk vanskelig diagnose på grunn av diffuse symptomer og sparsomme funn ved klinisk undersøkelse. Hovedsymptomet er intermitterende tegn til tarmobstruksjon, men kan også være akutte magesmerter. Tilstanden kan identifiseres ved CT-undersøkelse eller diagnostisk laparoskopi. Intern herniering utgjør 0,5-5,8 \% av tilfeller med tarmobstruksjon, mens intramesenterisk hernie er en sjelden variant (1-3). 
imaging and surgical findings. Radiographics 2016; 36: 88 - 106. [PubMed][CrossRef]

2. Martin LC, Merkle EM, Thompson WM. Review of internal hernias: radiographic and clinical findings. AJR Am J Roentgenol 2006; 186: 703 - 17. [PubMed][CrossRef]

3. Crispín-Trebejo B, Robles-Cuadros MC, Orendo-Velásquez E et al. Internal abdominal hernia: Intestinal obstruction due to trans-mesenteric hernia containing transverse colon. Int J Surg Case Rep 2014; 5:396 - 8. [PubMed][CrossRef]

Publisert: 4. september 2017. Tidsskr Nor Legeforen. DOI: 10.4045/tidsskr.17.009o Mottatt 25.1.2017, første revisjon innsendt 31.3.2017, godkjent 24.4.2017.

(C) Tidsskrift for Den norske legeforening 2020. Lastet ned fra tidsskriftet.no 